\title{
Pterodactyloid pterosaur bones from Cretaceous deposits of the Antarctic Peninsula
}

\author{
ALEXANDER W.A. KELLNER ${ }^{1 *}$, TAISSA RODRIGUES ${ }^{2}$, FABIANA R. COSTA ${ }^{3}$, LUIZ C. \\ WEINSCHÜTZ ${ }^{4}$, RODRIGO G. FIGUEIREDO ${ }^{5}$, GEOVANE A. DE SOUZA ${ }^{1}$, ARTHUR S. BRUM ${ }^{1}$, \\ LÚCIA H.S. ELEUTÉRIO ${ }^{6,7}$, CARSTEN W. MUELLER ${ }^{8}$ and JULIANA M. SAYÃO ${ }^{1,6}$
}

\footnotetext{
${ }^{1}$ Laboratory of Systematics and Taphonomy of Fossil Vertebrates, Departamento de Geologia e Paleontologia, Museu Nacional/ Universidade Federal do Rio de Janeiro, Quinta da Boa Vista s/n, São Cristóvão, 20940-040 Rio de Janeiro, RJ, Brazil

${ }^{2}$ Laboratório de Paleontologia, Departamento de Ciências Biológicas, Centro de Ciências Humanas e Naturais, Universidade Federal do Espírito Santo, Avenida Fernando Ferrari, 514, 29075-910 Vitória, ES, Brazil

${ }^{3}$ Laboratório de Paleontologia de Vertebrados e Comportamento Animal/LAPC, Centro de Ciências Naturais e Humanas/ CCNH, Universidade Federal do ABC, Rua São Paulo, s/n, Jardim Antares, 09606-045 São Bernardo do Campo, SP, Brazil ${ }^{4}$ CENPALEO - Centro Paleontológico da Universidade do Contestado, Universidade do Contestado, 89306-076 Mafra, SC, Brazil ${ }^{5}$ Departamento de Biologia, Universidade Federal do Espírito Santo, Alto Universitário, s/n, Guararema, 29500-000 Alegre, ES, Brazil

${ }^{6}$ Laboratório de Paleobiologia e Microestruturas, Centro Acadêmico de Vitória, Universidade Federal de Pernambuco, Rua do Alto Reservatório, s/n, Bela Vista, 55608-680 Vitória do Santo Antão, PE, Brazil ${ }^{7}$ Programa de Pós-Graduação em Geociências, Universidade Federal de Pernambuco/UFPE, Centro de Tecnologia e Geociências, Av. da Arquitetura, s/n, Cidade Universitária, 50740-550 Recife, PE, Brazil ${ }^{8}$ Technical University of Munich, Chair of Soil Science, Emil-Ramann-Strasse 2, 85354, Freising-Weihenstephan, Germany
}

Manuscript received on October 23, 2019; accepted for publication on November 6, 2019

How to cite: KELLNER AWA, RODRIGUES T, COSTA FR, WEINSCHÜTZ LC, FIGUEIREDO RG, SOUZA GA, BRUM AS, ELEUTÉRIO LHS, MUELLER CW AND SAYÃO JM. 2019. Pterodactyloid pterosaur bones from Cretaceous deposits of the Antarctic Peninsula. An Acad Bras Cienc 91: e20191300. DOI 10.1590/00013765201920191300 .

\begin{abstract}
Fossil vertebrates from Antarctica are considerably rare, hampering our understanding of the evolutionary history of the biota from that continent. For several austral summers, the PALEOANTAR project has been carrying out fieldwork in the Antarctic Peninsula in search for fossils, particularly Cretaceous vertebrates. Among the specimens recovered so far are two bones referable to Pterosauria, more specifically to the Pterodacyloidea, the first volant reptiles from Antarctica to be fully described. MN 7800-V (part and counterpart) was recovered from a moraine at the Abernathy Flats (Santa Marta Formation, Lachman Crags Member, Santonian-Campanian) on James Ross Island. It is interpreted as the distal articulation of a first phalanx of the wing finger, representing an animal with an estimated wingspan between 3 and $4 \mathrm{~m}$. The second specimen (MN 7801-V) comes from Vega Island (Snow Hill Island Formation, Maastrichtian) and is identified as a wing metacarpal IV of an animal with an estimated wingspan from 4 to $5 \mathrm{~m}$. These occurrences show that pterodactyloids inhabited the Antarctic Peninsula at least during the Upper Cretaceous and demonstrate that large pterosaurs were widespread through all parts of the planet during that period.
\end{abstract}

Key words: Antarctica, Antarctic Peninsula, Pterosauria, PALEOANTAR, Cretaceous.

Correspondence to: Alexander Wilhelm Armin Kellner

E-mail: kellner@mn.ufrj.br

ORCid: https://orcid.org/0000-0001-7174-9447

* Contribution to the centenary of the Brazilian Academy of

Sciences. 


\section{INTRODUCTION}

Pterosaurs were volant reptiles that existed for most of the Mesozoic Era, and became extinct at the end of the Cretaceous (e.g., Kellner 2006, Barrett et al. 2008). Their record is quite irregular, with a few deposits contributing to the majority of the recovered specimens and taxonomic diversity (Kellner 1994).

Until now, the only record of these flying reptiles reported from Antarctica is a humerus that was recovered from the Early Jurassic Falla Formation, in the Central Transantarctic Mountains (Hammer and Hickerson 1994). It was regarded as representing a "rhamphorhynchoid" (= nonpterodactyloid) and tentatively referred to the Dimorphodontidae (Hammer and Hickerson 1996). This specimen was subsequently figured but without a detailed description (Hammer and Hickerson 1999, fig. 5).

In 2006/2007, a team led by the Museu Nacional/UFRJ developed the project PALEOANTAR aiming to search for fossils at distinct locations of Northern Antarctic Peninsula (Kellner et al. 2011). All Brazilian scientific activities in Antarctica are funded by a special program of the Conselho Nacional de Desenvolvimento Científico e Tecnológico (CNPq) called PROANTAR (Programa Antártico Brasileiro - Brazilian Antarctic Program) and are developed in collaboration with the Brazilian Navy. Due to limitations of funding, only in the austral summer of 2015/2016 could the PALEOANTAR project resume, this time including several other institutions. During that field season, several researchers worked collaboratively at James Ross Island (the largest undertaking of PROANTAR), which included seven researchers of PALEOANTAR, five researchers of TERRANTAR (examining Antarctic soils), and three alpinists. Hundreds of fossils were collected, the majority housed at the Museu Nacional/UFRJ, including ichnofossils, several plant materials (e.g., logs, leaves, one pinecone, charcoal), invertebrates (e.g., ammonites, bivalves, corals, lobsters), teeth (sharks, bony fishes, plesiosaurs), and isolated bones (fish and reptiles). Among the specimens recovered during that field season is one bone divided into two parts (MN 7800-V) that is here referred to Pterosauria. Two years later, in the austral summer of 2017/2018, members of the PALEOANTAR project participated in field activities at Vega Island under the TERRANTAR project. Although this and subsequent expeditions to that island did not recover as many fossils as the $2015 / 2016$ field season, there is one incomplete element that represents a second pterosaur bone from the James Ross Archipelago (MN 7801V). Both specimens are described here, showing the presence of flying reptiles in the Antarctic Peninsula during the late Cretaceous (Fig. 1). They are housed in the paleovertebrate collection (Departamento de Geologia e Paleontologia) of the Museu Nacional (MN) - Universidade Federal do Rio de Janeiro (UFRJ).

\section{GEOLOGICAL SETTING}

The area prospected by PALEOANTAR is situated in the eastern portion of northern Antarctic Peninsula, more specifically at the northwestern part of the James Ross Archipelago where outcrops of the Larsen Basin are exposed (Fig. 1). The Larsen Basin is subdivided into the James Ross and Larsen sub-basins (Macdonald et al. 1988, Del Valle et al. 1992). The James Ross sub-basin was formed during the breakup of Gondwana and has one of the most complete sedimentary sequences from the Cretaceous to the Paleogene of the southern hemisphere (e.g., Crame et al. 1996). These deposits are divided into three groups: Nodenskjöld, Gustav and Marambio (Feldmann et al. 1993, Hathway 2000, Hathway and Riding 2001, Riding and Crame 2002), the latter being of 

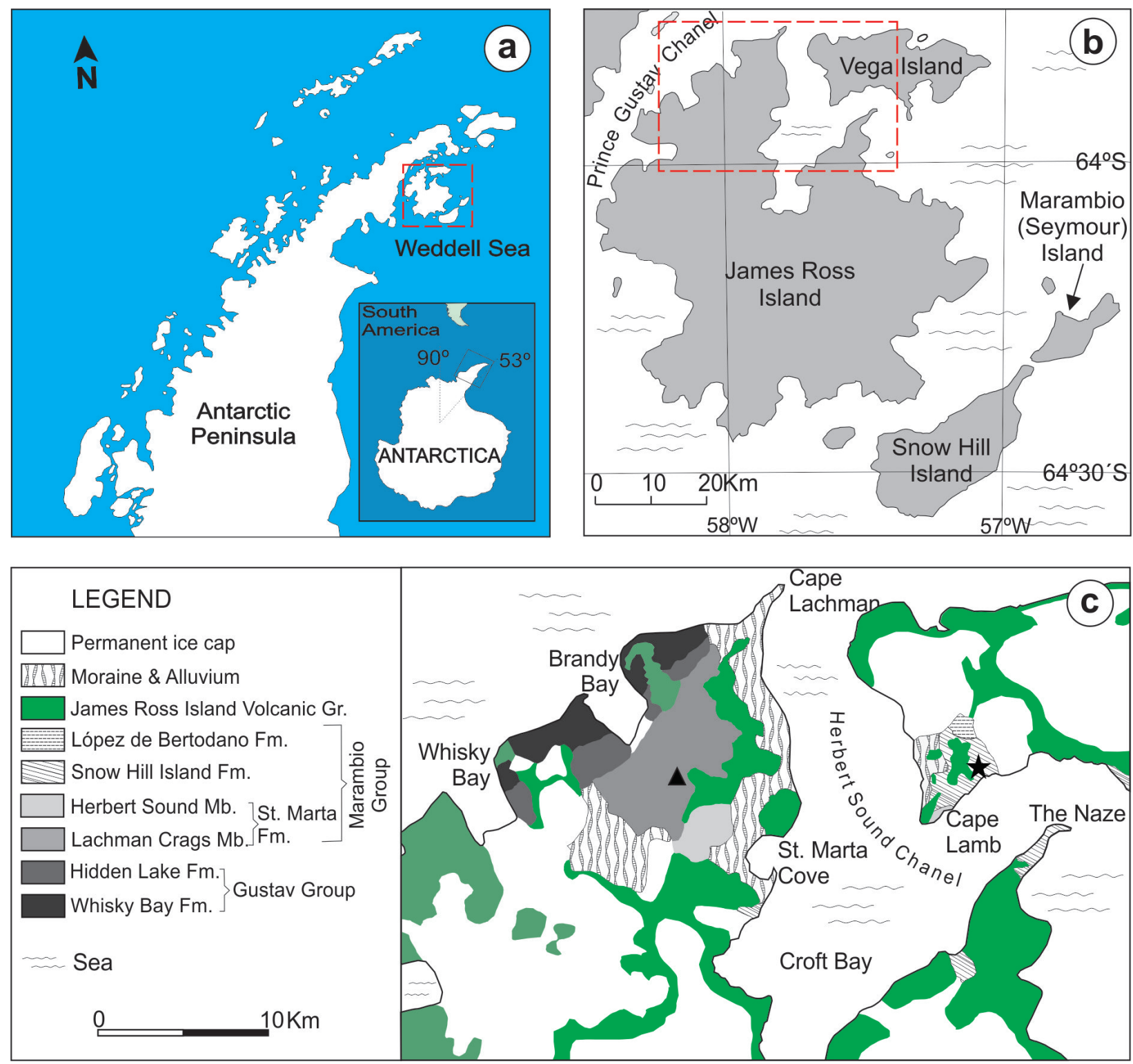

Figure 1 - Map showing the (a) location of the Antarctic Peninsula and (b) detail of the James Ross and Vega islands.where fieldwork was carried out. (c) Geologic map of the prospected area showing where the pterosaur material was collected: $\boldsymbol{\Delta}$ MN 7800-V from James Ross Island and $\star$ MN 7801-V from Veja Island.

interest in the present study (Crame et al. 2004, Fig. 2). Some new geologic data of the Snow Hill Island and the López de Bertodano formations are included here.

The Marambio Group crops out in several islands of the James Ross Archipelago, including James Ross and Vega islands (Crame et al. 1991). It comprises siliciclastic deposits, mainly sandstones, siltstones and mudstones that are intercalated with levels of coquina deposited under storm conditions on the internal and external platform (Crame et al. 2004). Four formations are recognized in the Marambio Group: Santa Marta, Snow Hill Island, López de Bertodano and Sobral (Fig. 2).

The Santa Marta Formation is the basal unit of the group and thought to have been deposited between the Santonian and Campanian (Olivero et al. 1986, Marenssi et al. 2001; Fig. 2). Sandstones, 


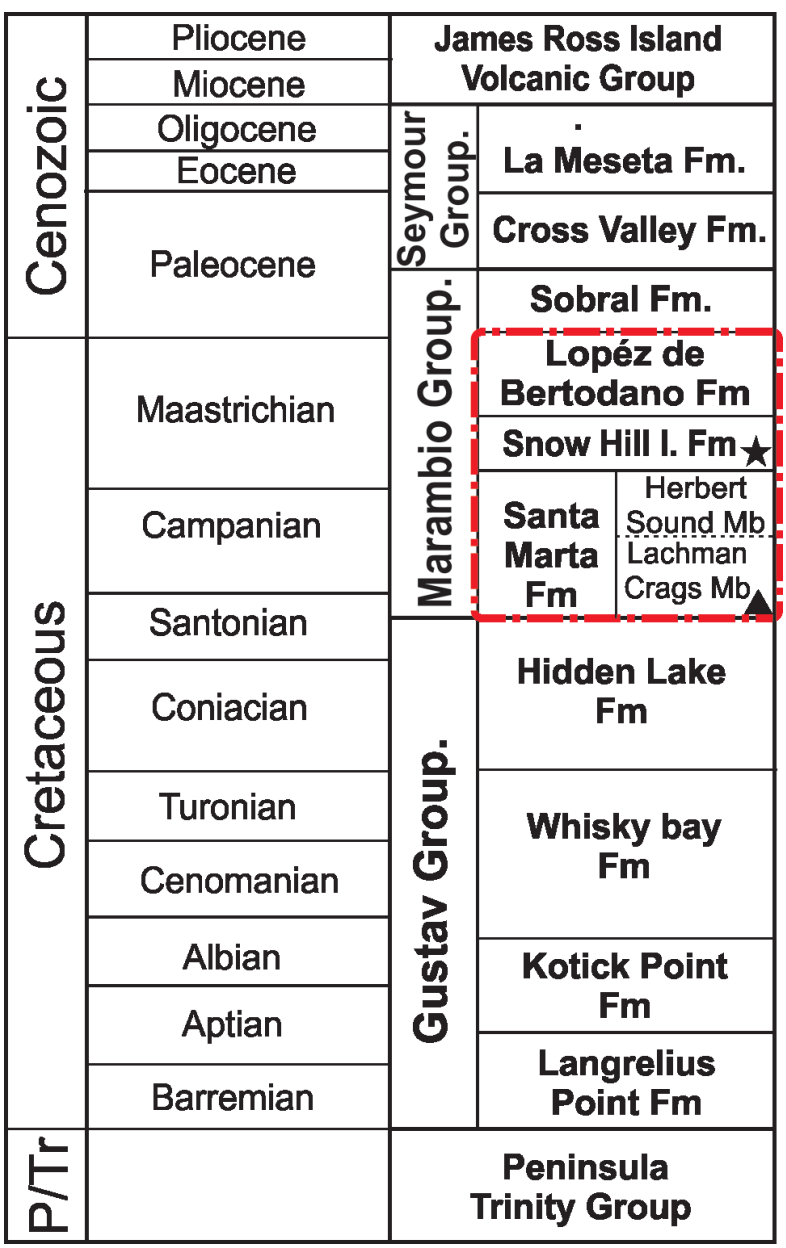

Figure 2 - Stratigraphic chart of the James Ross sub-basin, showing the units where specimens were recovered - $\boldsymbol{\Delta} \mathrm{MN}$ 7800 -V from James Ross Island and $\star$ MN 7801-V from the Vega Island. Modified from Olivero et al. (1986) and Marenssi et al. (2001).

siltstone, mudstone, volcanic tuffs and rare coquinas are the predominant lithologies, regarded as volcanoclastic deposits formed in a deltaic system (Scasso et al. 1991, Olivero 2012). In the northwestern portion of the James Ross Island, the Santa Marta Formation is divided into the Lachman Crags and the Herbert Sound members (Crame et al. 1991).

The Lachman Crags Member (SantonianCampanian) is also composed of siliciclastic rocks with rare conglomerates, reaching a thickness of about $850 \mathrm{~m}$ (Crame et al. 1991). It is overlain by the Herbert Sound Member (CampanianMaastrichtian), which consists of a $250 \mathrm{~m}$ section composed by fine sandstones with crossstratification and coquinas (Crame et al. 1991, Olivero et al. 1992, Olivero and Medina 2000).

The Snow Hill Island Formation (Maastrichtian) shows massive sandstones with parallel bedding and cross lamination on its base. Occasionally thin layers of dark and red bioturbated shales are found at a decimetric scale associated with layers with calcium carbonate cement that are up to $30 \mathrm{~cm}$ thick. Carbonate nodules are very common and occur in two levels at the medium portion of the section where invertebrate fossils are concentrated. According to Olivero (2012), these deposits were formed in a progradation deltaic system. Coarse to medium grained sandstones occur on the top of the sequence, followed by bioturbated sandstones and siltsones, also containing levels with fossiliferous concretions, which are interpreted as tidal deposits formed in a regressive environment (Pirrie et al. 1997).

The López de Bertodano Formation (Maastrichtian) crops out in the elevated areas of the Vega, Snow Hill and Seymour islands (Crame et al. 2004). On Vega Island, its contact with the underlying Snow Hill Island Formation is gradational and mostly covered by soil. It comprises fine to coarse grained massive sandstones, with dispersed rounded pebbles. The sandstones reach a thickness up to $3 \mathrm{~m}$, with a thin layer $(\sim 20 \mathrm{~cm})$ of carbonaceous mudstone at their top. On the lower portion of this unit, close to the contact with the Snow Hill Island Formation, fossils were collected by the project TERRANTAR in the field season of 2017/2018. This area, revisited by the PALEOANTAR project in $2018 / 2019$, is characterized by alternating bands of fine sandstones and friable mudstones with wavy lamination. They grade to lenticular deposits of different scales and represent tidal channels within a tidal-dominated estuarine environment (Olivero 
et al. 2007). This unit preserved the contact between the Late Cretaceous and the Paleogene (Milanese et al. 2019).

The last unit of the Marambio Group is the Sobral Formation (Paleocene) that crops out mostly at Seymour Island. It predominantly comprises fine sandstones and mudstones that were deposited during two transgressive-regressive cycles (Marenssi et al. 2012).

Both specimens studied here (MN 7800-V and MN 7801-V) were not collected in situ, but were found eroding on the surface, a common feature of fossil bones in the James Ross Archipelago. The specimen MN $7800-\mathrm{V}$ is formed by two parts regarded as belonging to the same bone (see Description) and was found at the Abernathy Flats (James Ross Island) by one of the authors (CWM) while collecting soil in the frame of the TERRANTAR project. He informed the occurrence to AWAK and LCW who collected the specimen. The Abernathy Flats consists of an extended flattened area between the Crame $\mathrm{Col}$ and the Paso San José, in front of the Brandy Bay. The area where the specimen was found (S635 $53^{\prime} 35,9^{\prime \prime} /$ W5 $57^{\circ} 55^{\prime} 47,3^{\prime \prime}$ ) is a moraine consisting of unlithified sediments of glacial origin with no outcrops nearby (Fig. 3). According to geologic maps, the rocks in that area belong to the Lachman Crags Member of the Santa Marta Formation (Fig. 2). It came from the middle portion of this unit, which suggests a Santonian-Campanian age. No other fossils were found in a radius of $\sim 200 \mathrm{~m}$.

The second specimen (MN 7801-V) was also the result of surface collecting, this time at Vega Island. It was found during field activity of the TERRANTAR project at the Cape Lamb area in 2017/2018, on the beach (Thales Nunes da Silva, personal communication). Outcrops of two main stratigraphic units occur in this area: the Snow Hill Island and the López de Bertodano formations, both Maastrichtian in age (Olivero et al. 1986, Marenssi et al. 2001). Field activity of the PALEOANTAR project in the austral summer of 2018/2019 established that most of the fossiliferous layers in the Cape Lamb area are located close to the contact between the Snow Hill and the López de Bertodano formations (S63 $51^{\circ} 53.0^{\prime \prime} \mathrm{x}$ W57034'20.0"). Based on the available geologic map, the region close to the beach are part of the Snow Hill Island formation, from where MN 7801-V most likely came.

\section{MATERIALS AND METHODS}

A portion of the counter part of the specimen MN $7800-\mathrm{V}$ was sampled for paleohistological analysis. While in the field, this bone was covered by thermoplastic resin (Paraloid B72) for protection purposes. The specimen was subsequently measured and photographed according to the protocol proposed by Lamm (2013) and the thin section was prepared using standard fossil histology techniques (Chinsamy and Raath 1992, Lamm 2013). The sample was embedded in clear epoxy resin RESAPOL T-208, catalyzed with BUTANOX M50, and cut with a diamond-tipped blade on a saw (multiple brands). The mounting-side of the section was wet-grounded using a metallographic polishing machine (AROPOL-E, Arotec LTDA) with Arotec abrasive papers of increasing grit size (60/P60, 120/P120, 320/P400, 1200/P2500) until a final thickness of 30-60 microns was reached.

The osteohistological structures were observed with an optical microscope in transmitted light mode. Parallel/crossed nicols and fluorescence filters were used to enhance birefringence. Histological images were taken using an AxioCam digital sight camera (Zeiss Inc., Barcelona, Spain) mounted to an Axio Imager.M2 transmitted light microscope (Zeiss Inc. Barcelona, Spain). Images were taken at 56x and 106x total magnification.

\section{DESCRIPTION}

The specimen MN 7800-V from James Ross Island consists of two elements that were found close to 


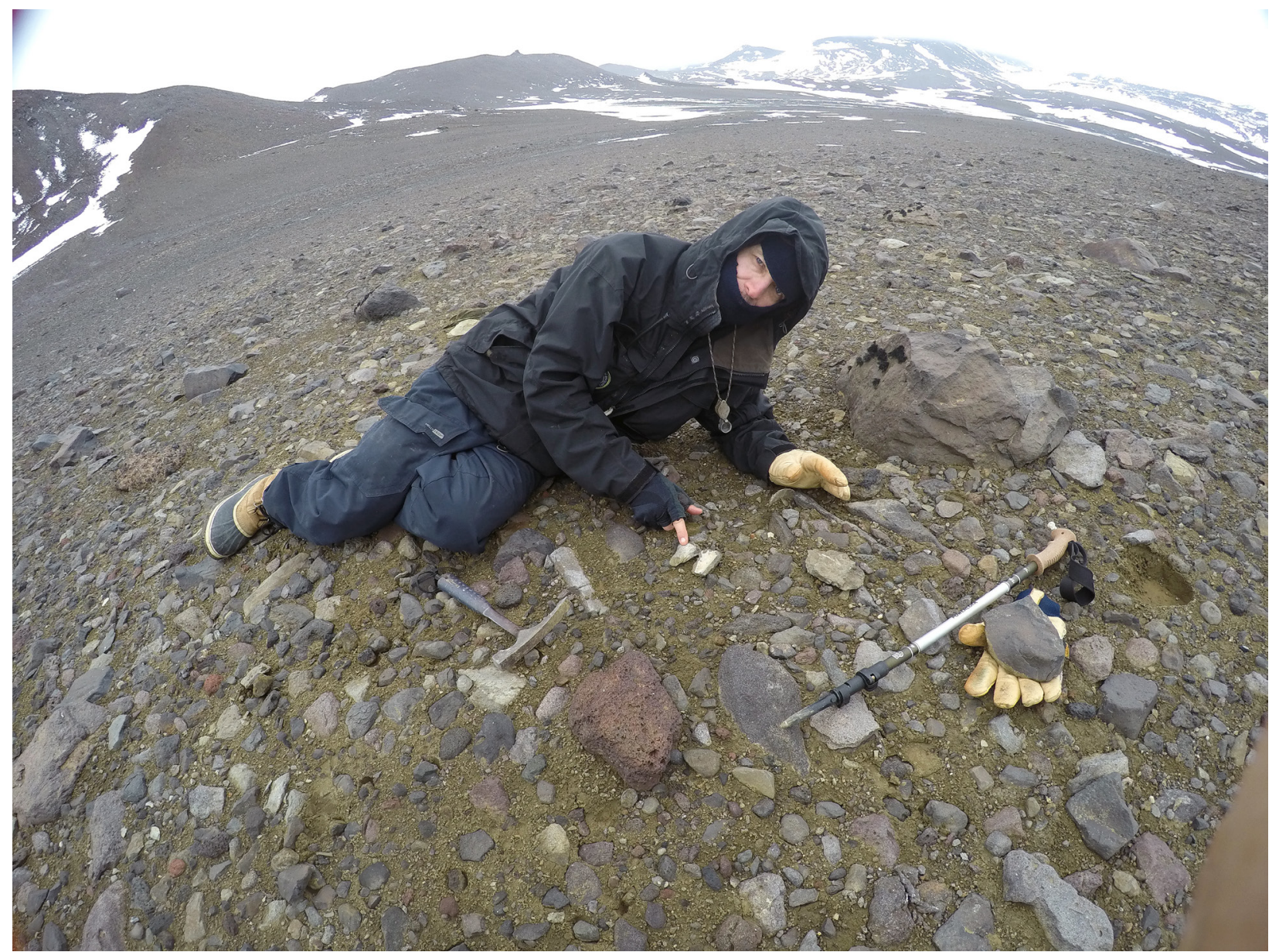

Figure 3 - The moraine at the Abernathy Flats in James Ross Island, at the moment where the specimen MN 7800-V was collected by AWAK and LCW.

each other in unlithified sediments with several large pebbles of different lithologies (Figs. 3, 4). One portion is preserved in three dimensions, an uncommon condition in pterosaurs (e.g., Bantim et al. 2014) whose bones are generally found very flattened (e.g., Cheng et al. 2017). The second part consists of a thin surface of bone preserved in a dark grey matrix formed by sandstone. Both pieces are about the same size and although the contact surface does not show a $100 \%$ fit because bone is missing, we regard them as representing the same element based on the overall morphology and the particular conditions where they were found.

The main preserved portion of MN $7800-\mathrm{V}$ has a maximum length of $67.8 \mathrm{~mm}$ (Figs. 5a, b). Several parts of the external bone surface were lost, but where measurable, the bone cortex is thin $(\sim 1$ - $1.5 \mathrm{~mm}$ ), thus congruent to pterosaur bones. It comprises a short shaft that expands forming a bootshaped articulation, which is typical of the distal end of pterosaur wing phalanges (e.g., Wellnhofer 1991a). The maximum width (mediolaterally) of the articulation is $52.1 \times 25.4 \mathrm{~mm}$.

A slice of the counterpart of MN 7800-V was taken for histological analysis (Fig. 5c). The osteohistological features are consistent with those observed in pterosaurs (see Steel 2008 for a review). The bone cortex is thin and presents a fibrolamellar tissue type (Fig. 5d). The vascular canals are longitudinal and have similar diameters, with no sign of anastomoses and composed only by primary osteons. As far as observations are 


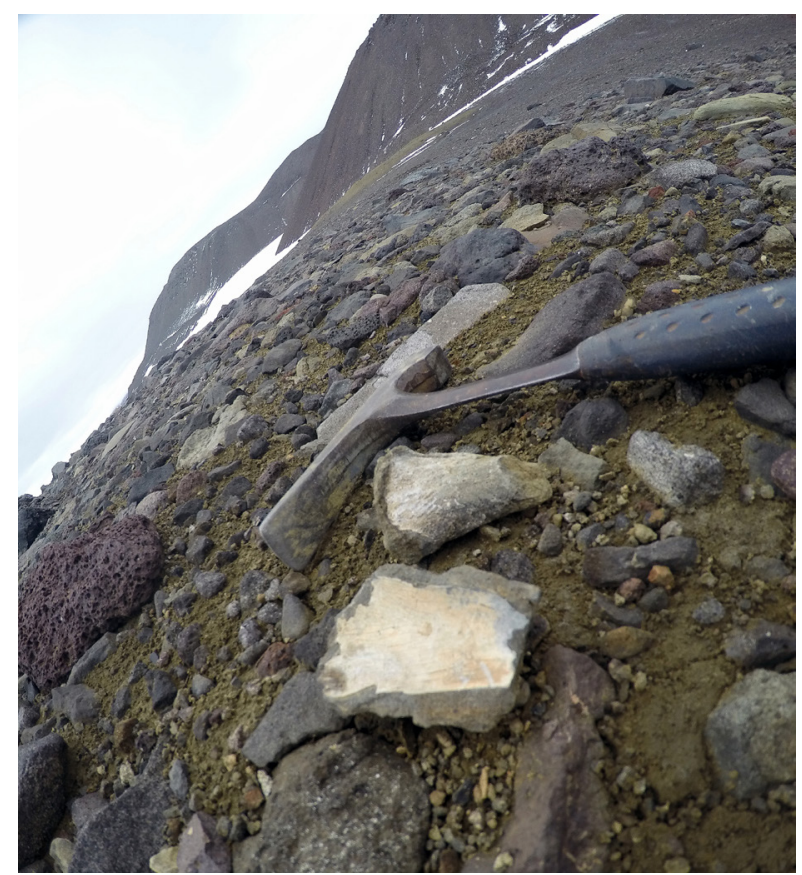

Figure 4 - Detail of MN 7800-V at the Abernathy Flats in James Ross Island.

possible, the endosteal cavity does not present internal lamellae. A film of thermoplastic resin applied on the specimen in the field, hinders the visualization of this part of the bone. A thin layer of avascular periosteal lamellae covers the outer surface. No growth marks such as zones, annuli or lines of arrested growth were observed. These structures are rarely preserved in pterosaurs due to the extensive endosteal resorption for the maintenance of the medullary cavity (Steel 2008, Prondvai et al. 2012), preserving only the most recent histological events. No resorption zones or secondary osteons were observed, which indicates no active remodeling in this individual at time of death.

The presence of avascular periosteal lamellae (External Fundamental System - EFS) has been used before to infer somatic maturity in sampled individuals, which indicates the ending of the development of the periosteal circumference (Cormack 1987, Starck and Chinsamy 2002, Ponton et al. 2004). However, bones can still become more robust (Woodward et al. 2011, Kellner et al. 2013, Lee and O'Connor 2013, Andrade et al. 2015). The EFS has already been recorded in mammals (e.g. Cormack 1987), birds (e.g. Ponton et al. 2004), non-avian dinosaurs (Erickson et al. 2004, Horner and Padian 2004, Padian et al. 2004), and crocodylomorphs (Woodward et al. 2011, Andrade et al. 2015). In pterosaurs, the EFS is so far restricted to a few specimens (Sayão 2003, Steel 2008, Kellner et al. 2013), being rare in nonpterodactyloid taxa with only two records (Gross 1934, De Ricqlès et al. 2000) and, so far, absent in many derived pterodactyloid groups such as azhdarchids. In all known occurrences of the EFS, the cortex is marked by the presence of LAGs, which were not seen in MN 7800-V, a feature that should be investigated further. Despite the absence of other microstructural features, we consider that the specimen was an adult that has or was about to complete its somatic growth.

Comparisons with osteohistological sections of other tetrapods reported from the same deposit, such as ornithopod dinosaurs and plesiosaurs, show important differences to MN 7800-V. Ornithopods have a more robust cortex, with weakly woven to parallel-fibered bone composing the primary bone and an outer cortex almost exclusively lamellar (Horner et al. 2009, Werning 2012). This clade also shows an inner cortex heavily remodeled by secondary osteons, extending into the mid-cortex with the total absence of original primary remains (Werning 2012). These osteohistological features differ from the fibrolamellar bone presented by MN $7800-\mathrm{V}$ that also lacks a remodeled cortex. Another difference is the presence of a cyclic growth in ornithopods characterized by multiple LAGs.

Plesiosaur osteohistology is very peculiar with bone matrix filling almost completely the medullar region, composing a dense osteosclerotic-like skeleton (Salgado et al. 2007, Ossa-Fuentes 2017). This differs remarkably from the condition of MN 


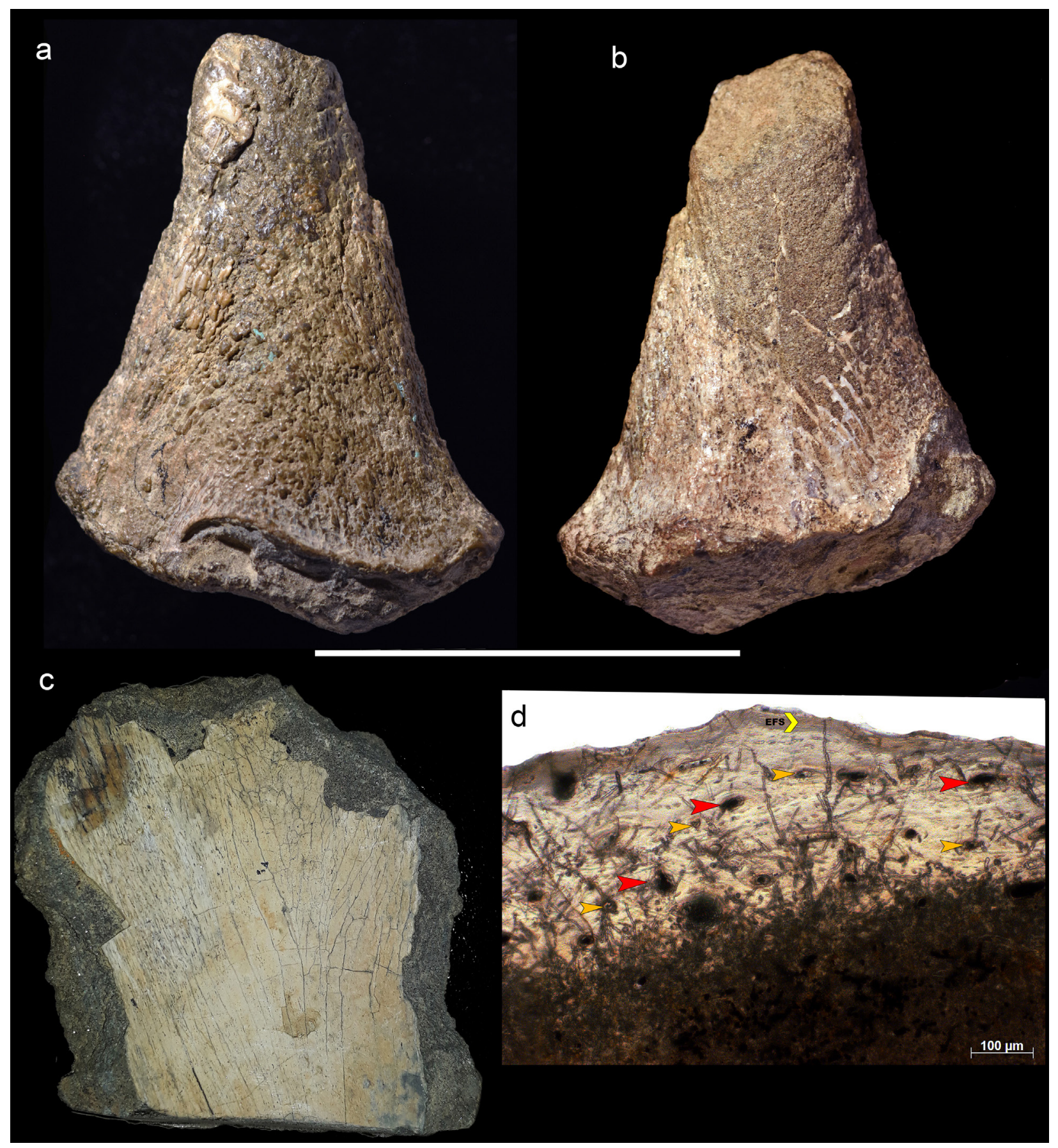

Figure 5 - MN 7800-V, (a) and (b) the main portion of the specimen, (c) the counterpart and (d) the osteohistological section showing the cortex formed basically by primary osteons marked by the arrows, in yellow the smallest vascular canals and in red more developed vascular canals. Scale bar for (a)-(c)=50mm, (d) $100 \mu \mathrm{m}$.

$7800-\mathrm{V}$ that presents a thinner cortex with a free medullary cavity.

The second specimen (MN 7801-V) described here comes from the Vega Island (Fig. 6). It consists of a long bone with a preserved length of $169.2 \mathrm{~mm}$ and lacks any articulation (Fig. 7). Originally, it was collected in one piece, but was further broken into three parts due to the fire of 


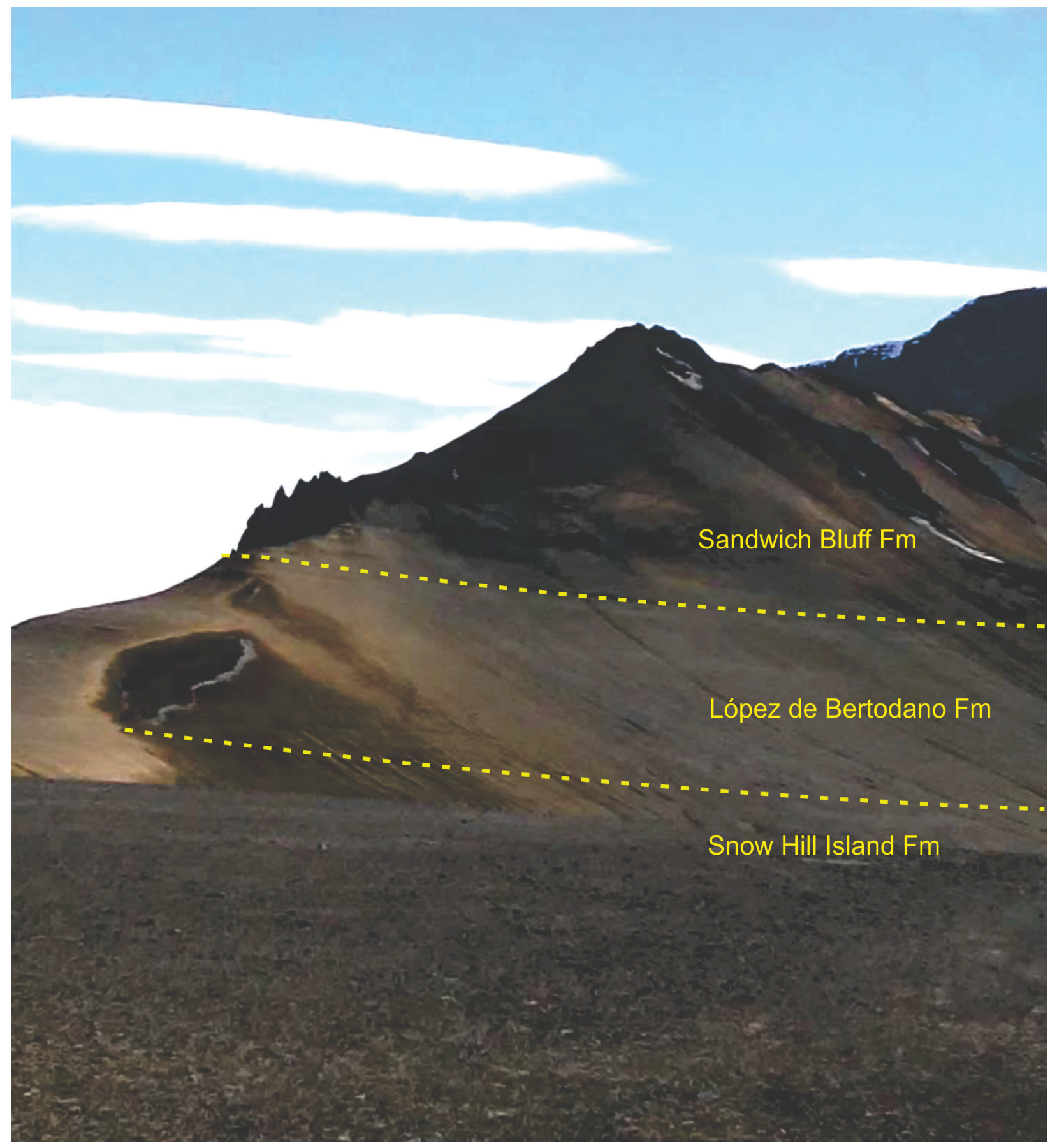

Figure 6 - Contact between the Snow Hill, López de Bertodano e Sandwich Bluff formations at the Vega Island.

the Museu Nacional (Kellner 2019). MN 7801-V is a naturally compressed element, with one side flattened (Fig. 7a), the other convex (Fig. 7c), and rounded margins. The shaft is slightly curved (Figs. $7 \mathrm{~b}, \mathrm{~d})$ and the transverse section at the middle portion is D-shaped ( $37 \times 22 \mathrm{~mm}$, Fig. 7e). The external bone surface is reasonably preserved and shows a very thin cortex $(\sim 0.8-1.2 \mathrm{~mm})$, tending to be thicker at the edges, a common condition in pterosaurs (Sayão 2003). 
a

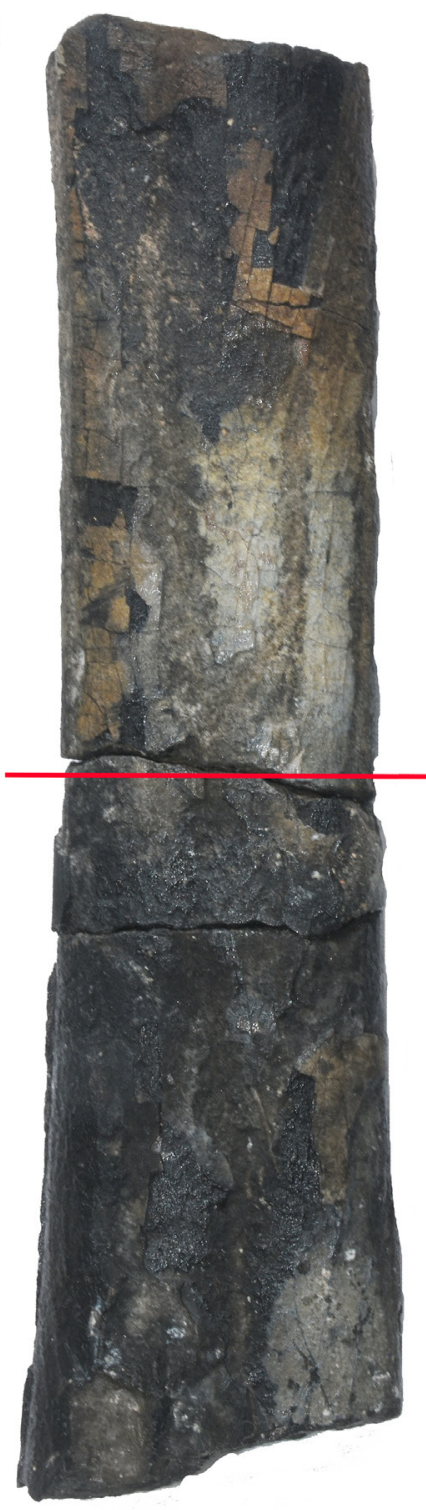

b

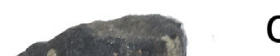

\section{(19)}

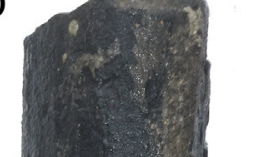

C

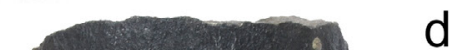

d

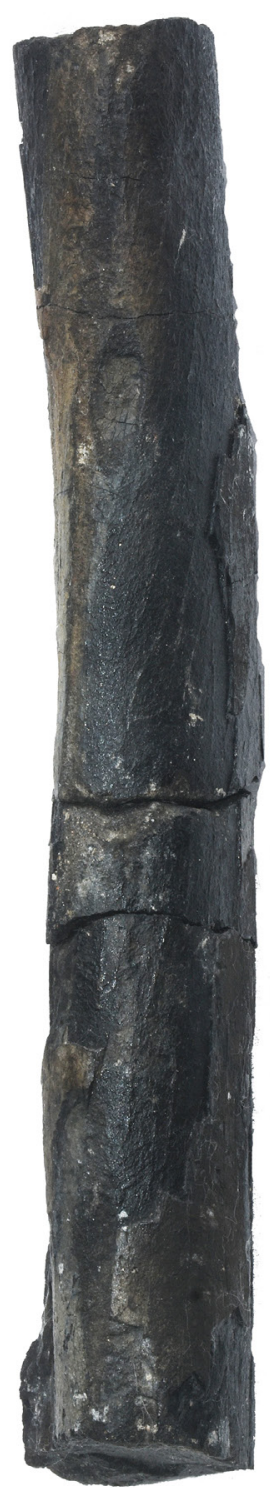

e

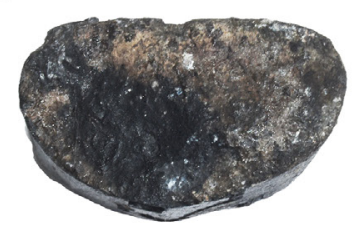

f

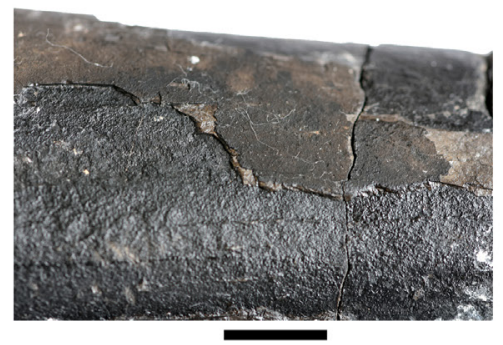

Figure 7 - MN 7801-V, interpreted as the right (?) wing metacarpal collected from Vega Island in (a) anterior, (b) ventral, (c) posterior and (d) dorsal view; (e) cross section at the middle portion of the shaft (marked by a red line in a), and (f) bone surface at the anterior view. Scale bars (a)-(e) $=100 \mathrm{~mm},(\mathrm{~F}) 10 \mathrm{~mm}$. 


\section{DISCUSSION}

Despite the efforts of several paleontological research groups (e.g., Molnar et al. 1996, Case et al. 2000, Novas et al. 2002, Salgado and Gasparini 2006, Reguero and Gasparini 2007, Reguero et al. 2013, Kellner et al. 2011, Cerda et al. 2012, Coria et al. 2013, Roberts et al. 2014, Lamanna et al. 2019), our knowledge on the Antarctic vertebrate fauna is still in its infancy. Due to the harsh conditions that predominate throughout the year, fieldwork is confined to the austral summer, when working conditions are more suitable but still very challenging. When found, the vast majority of fossil vertebrates is very incomplete, fragmentary and in many instances difficult to interpret. This is also the case off the material from James Ross and Vega islands. Unfortunately, no bone beds have been identified in both islands.

The specimen MN 7800-V from James Ross Island is a good example of the fragmentary nature of vertebrate fossils from Antarctica. It was recovered from a moraine, quite an unlikely place for any fossil bone to be found, especially that of a pterosaur. Notwithstanding, based on the overall expanded boot-shaped articulation and the thickness of the cortex, we interpret this specimen as belonging to the distal end of a pterosaur wing phalanx (Fig. 8). The osteohistological features are consistent with this interpretation. Although the boot-shaped expansion is a feature common to all distal ends of pterosaur wing finger phalanges (e.g., Wellnhofer 1991a, b, Kellner and Tomida 2000), we regard $\mathrm{MN} 7800-\mathrm{V}$ as belonging to the first wing finger phalanx mainly due to size. If this assignment is correct, when compared to other specimens the wingspan of the James Ross pterosaur would range between 3 and 4 $\mathrm{m}$. Such large wingspans are not seen in nonpterodactyloid pterosaurs, but are quite common within the Pterodactyloidea (e.g., Wellnhofer 1978, 1991a). Among pterodactyloids there are several clades represented by large flying reptiles (e.g., Kellner 2003), with the Pteranodontoidea or the Azhdarchoidea the best candidates to which MN 7800-V might be classified. The age of the main deposits of the Lachman Crags Member (SantonianCampanian) is consistent with this suggestion.

The identification of MN 7801-V from Vega Island as a pterosaur is less problematic. Despite the lack of articulations, the bone-surface is better preserved in this specimen, with a very thin bone cortex that is an uncontroversial pterosaurian feature. Its large size indicates that it is referable to the Pterodactyloidea as well. Based on size, we also preclude its referral to the Archaeopterodactyloidea, which comprises much smaller animals (Kellner 2003).

Regarding which part of the skeleton MN 7801-V represents, there are not many options to be considered. It is a long bone whose size and overall morphology leads to the exclusion of the hindlimb. Although size does not rule out that it could represent a phalanx from the wing finger, these bones tend to show a triangular to subtriangular transverse section (e.g., Wellnhofer 1978, 1991b) or are T-shaped (Martill and Frey 1998, Averianov 2014), differing from the D-shaped condition observed in $\mathrm{MN}$ 7801-V (Fig. 7e). The pterosaur ulnae are also quite long and somewhat anteroposteriorly compressed (e.g., Wellnhofer 1978, 1985, 1991b, Kellner and Tomida 2000, Bennett 2001), but their transverse section is more oval or rounded, differing from the Vega Island specimen. The metacarpal IV, however, is elongated and several of these elements show a D-shaped cross-section (e.g., Wellnhofer 1985, figure 15), quite similar to MN 7801-V. Therefore, we interpret this bone as being a wing metacarpal, possibly from the right side (Fig. 8).

The size of the Vega Island specimen is also consistent with either a pterosaur from the Pteranodontoidea or Azhdarchoidea clades, which have quite distinctive wing configurations (see Kellner 2003). The age of the Snow Hill 


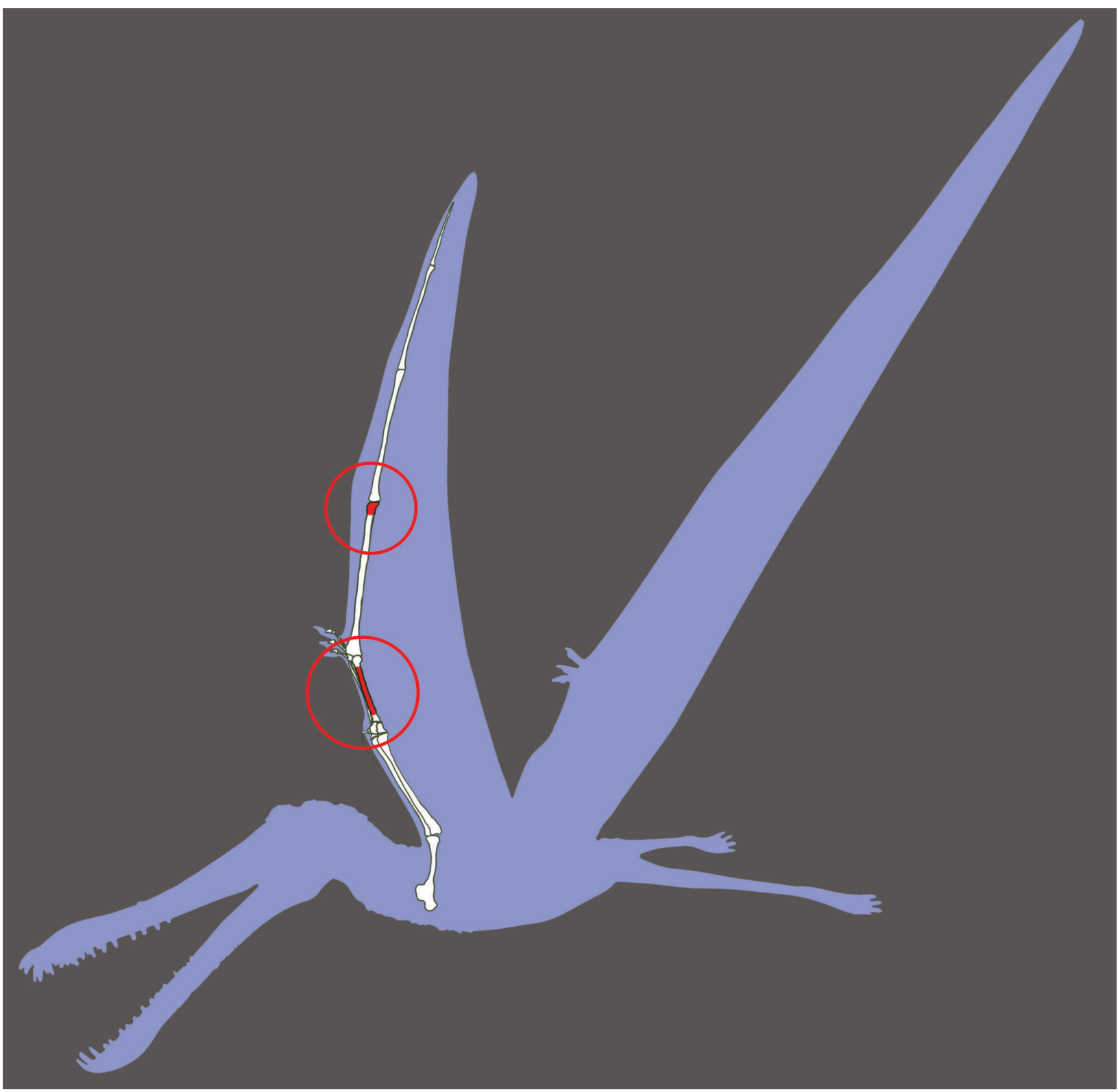

Figure 8 - General pterosaur outline showing the anatomical position of both specimens collected from the Antarctic Peninsula. MN 7800-V from the James Ross Island, interpreted as the distal end of the first phalanx of the wing finger (above), and MN 7801$\mathrm{V}$, identified as a wing metacarpal IV (below). Not to scale.

Island Formation, however, is Maastrichtian, when the most predominant flying reptiles were azhdarchoids, for all Azhdarchidae (e.g., Witton and Naish 2008, Averianov 2014, Longrich et al. 2018). Azhdarchoids have proven to be quite diverse in size (e.g., Martin-Silverstone et al. 2016) and ecological niche, with potentially different feeding strategies (e.g., Langston 1981, Witton and Naish 2008, Averianov 2014, Kellner and Calvo 2017, Bestwick et al. 2018, Kellner et al. 2019), and a cosmopolitan distribution. Although at this point no further taxonomic decision on MN 7801$\mathrm{V}$ can be made, it can be said to represent a large pterosaur with an estimated wingspan between 4-5 
$\mathrm{m}$ based on comparisons with other pterodactyloids (e.g., Wellnhofer 1991a, b, Kellner and Tomida 2000, Bennett 2001, Kellner 2003).

The sole other pterosaur specimen reported from Antarctica is a bone identified as a humerus that was briefly mentioned (Hammer and Hickerson 1994, 1996) and subsequently figured (Hammer and Hickerson 1999, fig. 5), but no anatomical description was presented so far. The published picture is difficult to interpret. If this specimen is complete and indeed represents a pterosaur humerus, this bone is shown from the lateral rather than from the dorsal view. The proximal articulation is expanded and the portion of the bone that might have been interpreted as the deltopectoral crest is triangular. Based on the anatomy of Dimorphodon humeri (e.g., Wellnhofer 1978, Padian 1983, Unwin 1988), the shaft is curved, differing from the straight bone reported from Antarctica. In Dimorphodon, the deltopectoral crest is longer, does not extend as deep on the shaft and is not triangular. If the reported bone from Antarctica is indeed pterosaurian, it differs from Dimorphodon and, based on the available information, cannot be assigned to any specific pterosaur clade.

\section{CONCLUSIONS}

Although very fragmentary, like most vertebrate fossils recovered from Antarctica, the specimens $\mathrm{MN} 7800-\mathrm{V}$ and $\mathrm{MN} 7801-\mathrm{V}$ indicate that large pterodactyloid pterosaurs were present in the Antarctic Peninsula region at least from the Santonian to the end of the Cretaceous. To our knowledge, these specimens are also the first from Antarctica to be fully described, demonstrating that at least during the Late Cretaceous, large flying reptiles could reach all parts of the planet. Continuous fieldwork in this region will certainly reveal additional and better-preserved material of these flying reptiles, filling in one of the gaps of our knowledge of their evolutionary history.
On a further note, we would like to point out that $\mathrm{MN} 7801-\mathrm{V}$ is the first specimen recovered from the debris of the Museu Nacional after the fire that affected this institution in 2018 (e.g., Kellner 2019) to be studied. Several important specimens were recovered so far, and we are sure that more will follow during the recovery and rebuilding activities of this worldwide important institution.

\section{ACKNOWLEDGMENTS}

This study was supported by the Programa Antártico Brasileiro (PROANTAR) through the Conselho Nacional de Desenvolvimento Científico e Tecnológico (CNPq \#407670/20130 and $\# 442677 / 2018$-9 to AWAK). The team of the PALEOANTAR Project wishes to thank all the NApOc Ary Rongel military group and the pilots of the HU-1 helicopter squadron for their logistic support during fieldwork in the Antarctic Peninsula, as well as the alpinists Edson Vandeira, Ricardo Leizer and Renato Dias from the Clube Alpino Paulista that organized the camping activities during the field seasons where the specimens studied here were collected. We would like to express our gratitude to Carlos Schaeffer, Maiara Daher, Eduardo Senra and Lars-Arne Meier of the TERRANTAR Project that camped with the PALEONTAR team at James Ross Island during the 2015/2016 field season. We are particularly indebted to Carlos Schaeffer (coordinator of the TERRANTAR Project) for providing access to members of the PALEOANTAR Project to join the 2017/2018 fieldwork in Vega Island. Guilherme Resende Corrêa, Rafael Gomes, Thales Nunes da Silva and Douglas Gonçalves are thanked for the fieldwork in Vega Island. Our special thanks to the team of the Museu Nacional/UFRJ in charge of the rescuing activities inside the Palace of the Quinta da Boa Vista park that is being coordinated by Claudia Rodrigues Carvalho and Luciana Carvalho, particularly Helder de Paula Silva, who recovered 
the Vega Island specimen (MN 78001-V) from the debris. Renan Bantim and Fabio Portugal are thanked for the pterosaur outline of Figure 8.

Besides PROANTAR, this study was partially funded by the Fundação de Desenvolvimento Carlos Chagas Filho de Amparo à Pesquisa do Estado do Rio de Janeiro (FAPERJ \#E-26/202.905/2018 to AWAK), Conselho Nacional de Desenvolvimento Científico e Tecnológico (CNPq \#420687/2016-5 and \#313461/2018-0 to AWAK; \#312360/20185 to TR; \#311715/2017-6 to JMS), Fundação de Apoio à Pesquisa do Estado de Pernambuco (FACEPE, - IBPG \#0419-9.05/16 to LHSE ), DFG Priority Programme 1158 "Antarctic Research with Comparable Investigations in Arctic Sea Ice Areas" (\#MU 3021/8-1 to CWA), Coordenação de Aperfeiçoamento de Pessoal de Nível Superior (CAPES \#88887.336584/2019-00 to ASB and \#88887.371713/2019-00 to GAS). We would also like to thank two anonymous reviewers for their suggestions.

\section{AUTHOR CONTRIBUTIONS}

AWAK, TR, LCW and JMS conceived and designed the study; AWAK, TR, FRC, LCW, RGF, GAS, ASB, CWM and JMS performed fieldwork in the Antarctic Peninsula collecting several fossil vertebrates that are housed in the Museu Nacional/ UFRJ; LCW conducted the geological study; LHSE and JMS did the osteohistological analysis. All authors reviewed and contributed to the manuscript.

\section{REFERENCES}

ANDRADE RC, BANTIM RAM, DE LIMA FJ, DOS SANTOS CAMPOS L, DE SOUZA ELEUTÉRIO LH AND SAYÃO JM. 2015. New data about the presence and absence of the external fundamental system in archosaurs. Cad Cult Cienc 14: 200-211.

AVERIANOV A. 2014. Review of taxonomy, geographic distribution and paleoenvironments of Azhdarchidae (Pterosauria). ZooKeys 432: 1-107.

BANTIM RAM, SARAIVAAAF, OLIVEIRA GAND SAYÃO JM. 2014. A new toothed pterosaur (Pterodactyloidea:
Anhangueridae) from the Early Cretaceous Romualdo Formation, NE Brazil. Zootaxa 3869: 201-223.

BARRETT PM, BUTLER RJ, EDWARDS NP AND MILNER AR. 2008. Pterosaur distribution in time and space: an atlas. Zitteliana B 28: 61-107.

BENNETT SC. 2001. Osteology and functional morphology of the Late Cretaceous pterosaur Pteranodon. Palaeontogr Abt A 260: 1-153.

BESTWICK J, UNWIN DM, BUTLER RJ, HENDERSON DM AND PURNELL. 2018. Pterosaur dietary hypothesis: a review of ideas and approaches. Biol Rev 93: 2021-2048.

CASE JA ET AL. 2000. The first duck-billed dinosaur (Family Hadrosauridae) from Antarctica. J Vertebr Paleontol 20: 612-614.

CERDA IA ET AL. 2012. The first record of a sauropod dinosaur from Antarctica. Naturwissenschaften 99(1): 8387.

CHENG X, JIANG S, WANG X AND KELLNER AWA. 2017. Premaxillary crest variation withing the Wukongopteridae (Reptilia, Pterosauria) and comments on cranial structures in pterosaurs. An Acad Bras Cienc 89: 119-130.

CHINSAMY A AND RAATH MA. 1992. Preparation of fossil bone for histological examination. Palaeontol Afr 29: 3944

CORIA R ET AL. 2013. A new ornithopod (Dinosauria: Ornithischia) from Antarctica. Cretac Res 41: 186-193.

CORMACK DH. 1987. Ham's Histology, 9th ed., Philadelphia: JB Lippincott Company, 732 p.

CRAME JA. FRANCIS JE, CANRILL DJ AND PIRRIE D. 2004. Maastrichtian stratigraphy of Antarctica. Cretac Res 25: 411-423.

CRAME JA, LOMAS SA, PIRRI, D AND LUTHER A. 1996. Late Cretaceous extinction patterns in Antarctica. J Geol Soc 153: 503-506.

CRAME JA, PIRRIE D., RIDING JB. AND THOMSON MRA. 1991. Campanian-Maastrichtian (Cretaceous) stratigraphy of the James Ross Island area, Antarctica. J Geol Soc Lond 148: 1125-1140.

DE RICQLÈS AJ, PADIAN K, HORNER JR AND FRANCILLON-VIEILLOT H. 2000. Palaeohistology of the bones of pterosaurs (Reptilia: Archosauris): anatomy, ontogeny, and biomechanical implications. Zool J Linn Soc-Lond 129: 349-385.

DEL VALLE RA, ELLIOT DH AND MACDONALD DIM. 1992. Sedimentary basins on the east flank of the Antarctic Peninsula: proposed nomenclature. Antarct Sci 4: 477-478.

ERICKSON GM, MAKOVICKY PJ, CURRIEPJ, NORELL MA, YERBY SA AND BROCHU CA. 2004. Gigantism and comparative life-history parameters of tyrannosaurid dinosaurs. Nature 430: 772-775.

FELDMANN RM, TSHUDY DM AND THOMSON MRA. 1993. Late cretaceous and paleocene decapod crustaceans from James Ross Basin, Antarctic Peninsula. Memoir, The Paleontological Society, p. 1-41. 
GROSS W. 1934. Die typen des mikroskopien knochenbaues bei fossilen Stegocephalen und Reptilien. Z Anat 103: 731764.

HAMMER WR AND HICKERSON WJ. 1994. A crested theropod dinosaur from Antarctica. Science 264: 828-830.

HAMMER WR AND HICKERSON WJ. 1996. Implications of an Early Jurassic Vertebrate Fauna from Antarctica. In: Morales M (Ed), The Continental Jurassic, Museum of Northern Arizona Bulletin 60, USA, p. 215-218.

HAMMER WR AND HICKERSON WJ. 1999. Gondwana dinosaurs from the Jurassic of Antarctica. Monogr Mus Nat Hist 15: 211-217.

HATHWAY B. 2000. Continental rift to back-arc basin: Jurassic-Cretaceous stratigraphical and structural evolution of the Larsen Basin, Antarctic Peninsula. J Geol Soc 157: 417-432.

HATHWAY B AND RIDING JB. 2001. Stratigraphy and age of the Lower Cretaceous Pedersen Formation, northern Antarctic Peninsula. Antarct Sci 13: 67-74.

HORNER JR AND PADIAN K. 2004. Age and growth dynamics of Tyrannosaurus rex. Proc R Soc B 271: 18751880 .

HORNER JR, DE RICQLÈS A, PADIAN K AND SCHEETZ RD. 2009. Comparative long bone histology and growth of the "hypsilophodontid" dinosaurs Orodromeus makelai, Dryosaurus altus, and Tenontosaurus tilletti (Ornithischia: Euornithopoda). J Vert Paleontol 29: 734-747.

KELLNER AWA. 1994. Remarks on pterosaur taphonomy and paleoecology. Acta Geologica Leopoldensia 39: 175-189.

KELLNER AWA. 2003. Pterosaur phylogeny and comments on the evolutionary history of the group. In: Buffetaut E and Mazin JM (Eds), Evolution and palaeobiology of pterosaurs, London: Geol Soc London Spec Pub 217(1): 105-137.

KELLNER AWA. 2006. Pterossauros: os senhores dos ceús do Brasil. Vieira \& Lent, Rio de Janeiro, 175 p.

KELLNER AWA. 2019. A reconstrução do Museu Nacional: bom para o Rio, bom para o Brasil. Ciência e Cultura 71: 4-5.

KELLNER AWA AND CALVO J. 2017. New azhdarchoid pterosaur (Pterosauria, Pterodactyloidea) with an unusual lower jaw from the Portezuelo Formation (Upper Cretaceous), Neuquén Group, Patagonia, Argentina. An Acad Bras Cienc 89: 2003-2012.

KELLNER AWA AND TOMIDA Y. 2000. Description of a new species of Anhangueridae (Pterodactyloidea) with comments on the pterosaur fauna from the Santana Formation (Aptian-Albian), northeastern Brazil. National Science Museum Monographs 17: 1-135.

KELLNER AWA ET AL. 2011. The oldest plesiosaur (Reptilia, Sauropterygia) from Antarctica. Polar Res 30: 1-6.

KELLNER AWA ET AL. 2013. The largest flying reptile from Gondwana: a new specimen of Tropeognathus cf. T. mesembrinus Wellnhofer, 1987 (Pterodactyloidea, Anhangueridae) and other large pterosaurs from the
Romualdo Formation, Lower Cretaceous, Brazil. An Acad Bras Cienc 85: 113-135.

KELLNER AWA, WEINSCHÜTZ LC, HOLGADO B, BANTIM RAM AND SAYÃO JM. 2019. A new toothless pterosaur (Pterodactyloidea) from Southern Brazil with insights into the paleoecology of a Cretaceous desert. An Acad Bras Cienc 91: e20190768.

LAMANNA MC ET AL. 2019. Late Cretaceous non-avian dinosaurs from the James Ross Basin, Antarctica: description of new material, updated synthesis, biostratigraphy, and paleobiogeography. Adv Polar Sci 30: 228-250.

LAMM ET. 2013. Bone histology of fossil tetrapods. In: Padian K AND Lamm ET (Eds), Preparation and sectioning of specimens, Oakland: University of California Press, USA, p. $55-160$.

LANGSTON JR W. 1981. Pterosaurs. Scientific American 244: 122-137.

LONGRICH NR, MARTILL DM AND ANDRES B. 2018. Late Maastrichtian pterosaur from North Africa and mass extinctions of Pterosauria at the Cretaceous-Paleogene boundary. PLoS Biol 16: e2001663.

LEE AH AND O'CONNOR PM. 2013. Bone histology confirms determinate growth and small body size in the noasaurid theropod Masiakasaurus knopfleri. J Vertebr Paleontol 33: 865-876.

MACDONALD DIM, BARKER PF, GARRETT SW, INESON JR, PIRRIE D, STOREY BC, WHITHAM AG, KINGHORN RRF AND MARSHALL JEA. 1988. A preliminary assessment of the hydrocarbon potential of the Larsen Basin, Antarctica. Marine and Petroleum Geology 5: 34-53.

MARENSSI S, SANTILLANA S AND BAUER M. 2012. Estratigrafía, petrografía sedimentaria y procedencia de las formaciones Sobral y Cross Valley (Paleoceno), isla Marambio (Seymour), Antártica. Andean Geology 39: 6791.

MARENSSI SA, SALANI FM AND SANTILLANA SN. 2001. Geología de cabo Lamb, Isla Vega, Península Antártica. Contrib Cient Inst Antart Argent 530: 1-43.

MARTILL DM AND FREY E. 1998. A new pterosaur lagerstatte in NE Brazil (Crato Formation; Aptian, Lower Cretaceous): preliminary observations. Oryctos 1: 79-85.

MARTIN-SILVERSTONE E, WITTON MP, ARBOUR VM AND CURRIE PJ. 2016. A small azhdarchoid pterosaur from the latest Cretaceous, the age of flying giants. Royal Society Open Science 3: 160333.

MILANESE FN, OLIVERO EB, RAFFI ME, FRANCESCHINIS PR, GALLO LC, SKINNER SM, MITCHELL RN, KIRSCHVINK JL AND RAPALINI AF. 2019. Mid-Campanian-lower Maastrichtian magnetostratigraphy of the James Ross Basin, Antarctica: chronostratigraphical implications. Basin Res 31: 562-583.

MOLNAR RE, LÓPEZ AA AND GASPARINI Z. 1996. An Antarctic Cretaceous theropod. Mem Queensland Mus 39: 669-674. 
NOVAS FE ET AL. 2002. Lakumasaurus antarcticus, n. gen. et sp., a new mosasaur (Reptilia, Squamata) from the Upper Cretaceous of Antarctica. Ameghiniana 39: 245-249.

OLIVERO EB. 2012. Sedimentary cycles, ammonite diversity and palaeoenvironmental changes in the Upper Cretaceous Marambio Group, Antarctica. Cretac Res 34: 348-366.

OLIVERO EB, MARTINIONI DR. AND MUSSEU FA. 1992. In: James Ross (Ed), Geología de la Isla, Upper Cretaceous sedimentology and biostratigraphy of western Cape Lamb (Vega Island, Antarctica). Implications on sedimentary cycles and evolution of the basin. Buenos Aires: Instituto Antártico Argentino, Argentina, p. 147-166.

OLIVERO EB AND MEDINA FA. 2000. Patterns of Late Cretaceous ammonite biogeography in southern high latitudes: the family Kossmaticeratidae in Antarctica. Cretac Res 21: 269-279.

OLIVERO EB, PONCE JJ, MARSICANO C AND MARTINIONI DR. 2007. Depositional settings of the basal Lopez de Bertodano Formation, Maastrichtian, Antarctica. Rev Asoc Geol Argent 62: 521-529.

OLIVERO EB, SCASSO RA AND RINALDI CA. 1986. Revision of the Marambio Group, James Ross Island, Antarctica. Contrib Cient Inst Antart Argent 331: 1-28.

OSSA-FUENTES L, OTERO RA AND RUBILAR-ROGERS D. 2017. Microanatomy and osteohistology of a juvenile elasmosaurid plesiosaur from the upper Maastrichtian of Marambio (=Seymour) island, Antartica. Bol Mus Nac Hist Nat Chile 66: 149-160.

PADIAN K. 1983. Osteology and functional morphology of Dimorphodon macronyx (Buckland) (Pterosauria: Rhamphorhynchoidea) based on new material in the Yale Peabody Museum. Postilla 189: 1-44.

PADIAN K, HORNER JR AND DE RICQLÈS AJ. 2004. Growth in small dinosaurs and pterosaurs: the evolution of archosaurian growth strategies. Paleontology 24: 555- 571.

PIRRIE D, CRAME JA, LOMAS SA AND RIDING JB. 1997. Late Cretaceous stratigraphy of the Admiralty Sound region, James Ross Basin, Antarctica. Cretac Res 18: 109137.

PONTON F, ELZANOWSKI A, CASTANET J, CHINSAMY, A, DE MARGERIE E, DE RICQLÈS AJ AND CUBO J. 2004. Variation of the outer circumferential layer in the limb bones of birds. Acta Ornithol 39: 137-140.

PRONDVAI E, STEIN K, ÖSI A AND SANDER MP. 2012. Life history of Rhamphorhynchus inferred from bone histology and the diversity of Pterosaurian growth strategies. Plos One 7: e31392.

REGUERO MAAND GASPARINI Z. 2007. Late Cretaceousearly Tertiary marine and terrestrial vertebrates from James Ross Basin, Antarctic Peninsula: a review. In: Rabassa $\mathrm{J}$ and Borla ML (Eds), Antarctic Peninsula \& Tierra del Fuego: 100 years of Swedish-Argentine scientific cooperation at the end of the world. London: Taylor \& Francis, England p. 55-76.
REGUERO MA ET AL. 2013. Late Cretaceous dinosaurs from the James Ross Basin, West Antarctica. Geol Soc Lond Spec Pub 381: 99-116.

RIDING JB AND CRAME J. 2002. Aptian to Coniacian (Early-Late Cretaceous) palynostratigraphy of the Gustav Group, James Ross Basin, Antarctica. Cretac Res 23: 739760.

ROBERTS EM ET AL. 2014. Stratigraphy and vertebrate paleoecology of Upper Cretaceous-?lowest Paleogene strata on Vega Island, Antarctica. Palaeogeogr Palaeocl 402: $55-72$.

SALGADO L, FERNÁNDEZ M AND TALEVI M. 2007 Observaciones histológicas en reptiles marinos (Elasmosauridae y Mosasauridae) del Cretácico Tardío de Patagonia y Antártida. Ameghiniana 44: 513-523.

SALGADO L AND GASPARINI Z. 2006. Reappraisal of an ankylosaurian dinosaur from the Upper Cretaceous of James Ross Island (Antarctica). Geodiversitas 28: 119135.

SAYÃO JM. 2003. Histovariability in bones of two pterodactyloid pterosaurs from the Santana Formation, Araripe Basin, Brazil: preliminary results. Geol Soc London 1: 335-342.

SCASSO RA, OLIVERO EB AND BUATOIS LA. 1991. Lithofacies, biofacies, and ichnoassemblage evolution of a shallow submarine volcaniclastic fan-shelf depositional system (Upper Cretaceous, James Ross Island, Antarctica). J S Am Earth Sci 4: 239-260.

STARCK JM AND CHINSAMY A. 2002. Bone microstructure and developmental plasticity in birds and other dinosaurs. J Morphol 254: 232-246.

STEEL L. 2008. The palaeohistology of pterosaur bone: an overview. Zitteliana 28: 109-125.

UNWIN DM. 1988. New remains of the pterosaur Dimorphodon (Pterosauria: Rhamphorhynchoidea) and the terrestrial ability of early pterosaurs. Modern Geology 13: $57-68$

WELLNHOFER P. 1978. Pterosauria. Handbuch der Paläoherpetologie, Teil 19. Stuttgart: Gustav Fischer Verlag, $82 \mathrm{p}$.

WELLNHOFER P. 1985. Neue Pterosaurier aus der SantanaFormation (Apt) der Chapada do Araripe, Brasilien. Palaeontographica abt A 105-182.

WELLNHOFER P. 1991a. The Illustrated Encyclopedia of Pterosaurs; London (Salamander Books), 192 p.

WELLNHOFER P. 1991b. Weitere Pterosaurierfunde aus der Santana-Formation (Apt) der Chapada do Araripe, Brasilien. Palaeontogr Abt A 215: 43-101.

WERNING S. 2012. The ontogenetic osteohistology of Tenontosaurus tilletti. Plos ONE 7: e33539.

WITTON MP AND NAISH D. 2008. A reappraisal of azhdarchid pterosaur functional morphology and paleoecology. PloS One 3: e2271.

WOODWARD HN, HORNER JR AND FARLOW JO. 2011. Osteohistological evidence for determinate growth in the American Alligator. J Herpetol 45: 339-342. 